\title{
O nie świętym Tertulianie, czyli jak to z rygoryzmem bywalo
}

Ks. Waldemar Turek, TERTULIAN, opracowanie i wybór tekstów, [w:] Ojcowie Żywi XV, seria pod redakcja ks. Marka Starowieyskiego, Wydawnictwo WAM, Księża Jezuici, Kraków 1999, ss. 296

Gdy prześledzić tomy serii wydawniczej Ojcowie Żywi, czytelnik zdaje sobie sprawę, że choć małe, wręcz kieszonkowe wydania, to zawierają one teksty patrystyczne oraz opracowania zagadnień z zakresu antyku chrześcijańskiego o wielkim znaczeniu. W tomach $\mathrm{z}$ tej serii odnaleźć można tematy żywotnie związane, tak z codzienną egzystencją chrześcijan świata antycznego, jak i z nauczaniem moralno-dogmatycznym Ojców Kościoła. Do pełnego obrazu rzeczywistości chrześcijańskiego antyku, choć nie tylko antyku, wspaniałe tło stanowia trzy tomy pod wspólnym tytułem Muza chrześcijań$s k a$, poświęcone poezji ${ }^{1}$. Obrazowo rzecz ujmując, księgi te nie tylko tętnia życiem pierwszych chrześcijan, ale również słychać w nich głosy, z jednej strony pasterzy, a z drugiej wiernych tego Kościoła. Zasługą największą tej serii jest to, że poprzez przystępną formę opracowania zagadnień i ciekawie dobrane teksty źródłowe, stała się ona łatwą do „przełknięcia”, nawet dla laika. Dzięki temu zaś przyczyniła się do popularyzacji autentycznej duchowości pierwszych chrześcijan, oraz myśli Ojców Kościoła szerokiemu gronu odbiorców.

Jeśli do tomu trzynastego włącznie seria podejmowała raczej rozważania dotyczące jakiegoś konkretnego tematu (np.: męczeństwa, eucharystii, czy pielgrzymowania), wciaggając niejako do dyskusji pisarzy antyku chrześcijańskiego poprzez wykorzystanie ich twórczości. To w ostatnich dwóch tomach Autorzy podjęli się prezentacji wybitnych postaci Kościoła chrześcijańskiego. W tym miejscu należy się pochwała dla redaktora serii ks. prof. Marka Starowieyskiego, gdyż już w pierwszych czterech tomach „do zbioru włączono nieśmiało [jak sam pisał] teksty braci odłączonych" (t. I, s. 13). Po piętnastu zaś latach, ks. profesor postępuje znacznie już śmielej, gdyż pierwsze dwa opracowania poświęcone zostały postaciom tyle wspaniałym, co kontrowersyjnym, a zwykle pomijanym lub wspominanym dość marginalnie,

${ }^{1}$ Rzecz wyjatkowej wartości, w j. polskim znajdują się co prawda tłumaczenia poezji chrześcijańskiego antyku. Najszerzej potraktowane w dwóch seriach: Pismach Starochrześcijańskich Pisarzy (PSP, t.: XI, XLIII, LIII), wydawnictwa ATK z Warszawy; oraz Głosie Tradycji (min. bogaty zbiór poezji św. Efrema), wydawanym przez ks. W. Kanię w Tarnowie. Ale tak szerokiego przeglądu poezji chrześcijańskiej, tak pod względem czasowym (od II-XV w.), jak i przestrzenno-kulturowym (całość terenów Cesarstwa rzymskiego, a właściwie całość terenów schrystianizowanych), polski rynek księgarski jeszcze nie goscił. 
w książkach z zakresu historii Kościoła. Tom XIV zawiera opracowanie i wybór z pism monofizyckiego pisarza ormiańskiego pochodzenia Nersesa Šnorhaliego (1102-1173). Tom zaś XV, którym się tutaj bliżej zajmiemy, przedstawia osobę Tertuliana z Kartaginy (ok. 160-220) pisarza chrześcijańskiego pochodzącego z Afryki rzymskiej, którego wybory życiowe rzuciły na bezdroża skrajnego rygoryzmu.

Kartagina przełomu II i III wieku była wręcz wymarzonym miejscem, aby mógł w niej wzrastać człowiek o umyśle tak żywym i sercu tak gorącym jak Tertulian. Ludność Afryki Północnej bowiem stanowiła niecodzienną mieszankę: Fenicjan (od IX w. p.n.e.), Greków (od VI w. p.n.e.), Rzymian (od II w. p.n.e.) i ludności autochtonicznej (Afrów, Numidów, Getulów i Maurów) tzw. Berberyjskiej. Jak widać społeczeństwo afrykańskie okresu rzymskiego było tworzone przez zbitkę narodowości o bardzo różnych temperamentach $\mathrm{i}$ charakterach, co w rezultacie dawało środowisko twórcze, ale skłonne do nieprzewidywalnych wręcz reakcji. Tertulian - syn oficera rzymskiego, pochodził właśnie $\mathrm{z}$ takiego środowiska. Urodzony ok. 160 roku w Kartaginie, w której otrzymał wykształcenie podstawowe i średnie (używając dzisiejszej nomenklatury). Na studia filozoficzno-prawnicze wybrał się najprawdopodobniej do Rzymu, gdzie został wziętym prawnikiem. Wraca jednak do Afryki. Jako nieodrodne „dziecko" epoki jest stałym bywalcem amfiteatrów i tu, zdaje się podczas męczeństwa wyznawców Chrystusa, poruszony świadectwem niespotykanej odwagi chrześcijan przeżywa swoje nawrócenie. „Każdy bowiem widząc tego rodzaju wytrzymałość, uderzony jakimś niepokojem sumienia zaczyna się zastanawiać, o co tu właściwie chodzi. Gdy zaś pozna prawdę natychmiast ustępuje" (Tertulian, Do Skapuli, 5, PSP XXIX, s. 116). Od tego momentu jego życie ulega diametralnej zmianie. Wszystko zostaje podporządkowane wypełnianiu przykazań Ewangelii. Tertulian staje się adwokatem chrześcijan. Znaczna część z jego pisarskiego dorobku (15 z 31 traktatów) poświęcona zostaje polemikom, które przenika prawnicza mentalność ich autora, zmieniają się tylko tematy i adwersarze. Nawet w traktatach o treści dogmatycznej, czy praktyczno-ascetycznej, trudno wyzbyć się uczucia, że Kartagińczyk również tutaj z kimś dyskutuje. Ale właśnie dzięki przyjętej przez niego formie pisarskiej wyrosło takie wspaniałe dzieło jak: Apologetyk (Pisma Ojców Kościoła XX, Poznań 1947), który osiagnał mistrzostwo w swojej kategorii. Można pokusić się o twierdzenie, że doszło do tego za sprawa jego afrykańskich korzeni, które ujęte jednak zostały w karby rzymskiego wychowania i wykształcenia. Niestety ta właśnie cecha, która ze wszech miar predestynowała go do podjeccia się obrony chrześcijan stała się dla niego piętą Achillesowa, gdyż wymogi sprawiedliwości przysłoniły mu nieomal całkowicie miłosierdzie Boga.

Do tej pory przyglądano się Tertulianowi w rozmaity sposób i z różnorakiej perspektywy, częstokroć nie zostawiając na tym chrześcijańskim pisarzu przysłowiowej suchej nitki. Jeśli bowiem chętnie cytuje się jego dzieła, to zwykle pomija się milczeniem ich autora lub mówi o nim, lecz z niejakim zażenowaniem. Rodzi się pytanie: z czego wypływa taka postawa? Najogól- 
niej rzecz biorąc można powiedzieć, że z wielkich uproszczeń dotyczących sądów o Tertulianie. Zwykle bowiem bierze się pod uwage jego poglądy moralne i skłonności do rygoryzmu, a oceniając je z punktu widzenia dzisiejszej nauki Kościoła wyrok zapada surowy i bez szansy na apelację. Werdykt w najlepszym wypadku brzmi: schizmatyk. Największym zaś „grzechem”, podczas oceny Kartagińczyka, jest pomijanie czynników zewnętrznych (min.: czas, miejsce, środowisko) i wewnętrznych (np.: temperament, czy wychowanie), które kształtowały jego sposób odbierania i pojmowania rzeczywistości. Dlatego podczas poniższego przeglądu zwrócona zostanie szczególna uwaga na zagadnienia rygoryzmu i radykalizmu Tertuliana. Ta bowiem tematyka: po pierwsze, jest wiodącą w większości opracowań dotyczących samego Kartagińczyka; po drugie - co ważniejsze, w znacznej mierze wypełnia jego dorobek pisarski. Po trzecie - na koniec, najlepiej ukarze ona to, czy i w jakim stopniu udało się ks. Turkowi wejść w skomplikowaną problematykę związaną z osobowością i twórczością Afrykańczyka.

Niemal od pierwszych stron opracowania, zaraz po rysie biograficznym, spotykamy się z interesującą nas kwestią. Świadczy to o zrozumieniu wagi problemu i natychmiastowym ustawieniu właściwej hierarchii zagadnień. Autor pisze bowiem, że „Tertuliana (...) wykazywał często tendencje do rygoryzmu zarówno w spekulatywnym poszukiwaniu jak i w życiu praktycznym" (s. 19), ale czynił to, „szukając zawsze możliwie najlepszych rozwiązań" (s. 21), w proponowaniu społeczności chrześcijańskiej wzorców doskonałości. „Nie odbyło się to bez pojawiających się w takich przypadkach propozycji przesadnych". Ks. Turek zamyka tę myśl konkludując: „Jest jednak poważnym błędem oceniać Tertuliana tylko $\mathrm{z}$ punktu widzenia naszego sposobu rozumienia i widzenia świata" (s. 21). Zdania te świadczą o dwóch rzeczach: po pierwsze, o umiejętności zdystansowania się do powszechnie panujących sądów o kartagińskim pisarzu; a po drugie, o zdolności głębokiego wniknięcia w atmosferę czasu i miejsca. Fakt ten sprawia, że Autor opracowania nie zadowala się ukutymi w ciagu wieków poglądami, ale spokojnie, odsuwając wszelkie uprzedzenia, próbuje przybliżyć nam nie tylko wielce kontrowersyjnego pisarza; ale również, a może nawet przede wszystkim, człowieka, któremu przyszło żyć i działać w wielce skomplikowanej rzeczywistości Afryki Północnej przełomu II/III wieku.

Zastosowana w opracowaniu kolejność rozpatrywanych zagadnień, jak również tematyka w nich poruszana, stanowią świadectwo tego, że czytelnik będzie prowadzony drogą może nie najprostszą, ale najwłaściwszą, aby zrozumieć: rozwój, postępowanie, a w efekcie życie i twórczość Tertuliana ${ }^{2} \mathrm{Na}$ początku uwaga nasza skierowana została w stronę: osobowości, prawniczego wykształcenia i filozoficznych przekonań Kartagińczyka. Elementy te sta-

${ }^{2}$ Podobnej metody, choć $w$ znacznie szerszym stopniu traktując o zagadnieniach pomocniczych, użył przed półwieczem w biografii Tertuliana prof. Sajdak (J. Sajdak, Q. S. F. Tertulianus. Czasy - życie - dzieła, Poznań 1949) i należy przyznać, że do tej pory, w j. polskim nikt mu pod tym względem nie dorównał. 
nowią swoisty klucz do zrozumienia tendencji rygorystycznych, o których Autor mówi w dalszej części (rozdz. 4). Jeśli bowiem radykalizm życiowy prowadził Tertuliana prosto do nurtów milenarystycznych w Kościele (,,oczekiwat prawie jak wszyscy chrześcijanie tamtego czasu, rychtego drugiego przyjścia Pana" s. 22), to radykalizm etyczny, którego korzeni należy szukać w jego pierwszej fascynacji jaką była filozofia stoicka, w połączeniu $\mathrm{z}$ krewkim temperamentem doprowadza go do rygoryzmu. Dramatu dopełnia to, że Tertulian prawnik nie zrozumiał miłosierdzia Nowego Testamentu, które wypełniło prawo Starego Przymierza. „Tak więc występuje u pisarza wyraźna tendencja sprowadzania dzieła Zbawiciela do ogłoszenia nowego prawa i nowej obietnicy królestwa niebieskiego" (s. 27). W tym miejscu czytelnika opracowania, który oczekiwał by jakiegoś rozwinięcia tematu spotyka niedosyt. Do tej bowiem pory treść jest spójna wybór materii opracowania trafny i uzasadniony, ale ks. Turek, nie wiedzieć czemu, przerywa rozważanie pisząc jedynie, że „pisarz zbyt często próbował oprzeć wiele elementów swoich teologicznych rozważań jedynie na podstawach prawnych". To „spowodowało (...), znaczne spłycenie rozważań dotyczących wielu dziedzin teologicznych”, oraz „narzucenie zachodniemu sposobowi myślenia pewnej struktury prawnej zauważalnej często u późniejszych autorów" (s. 27-28). Wnioski jak najbardziej słuszne. Dlaczego jednak Autor, który do tej pory doskonale sygnalizuje, punkt po punkcie najistotniejsze momenty wpływające na zmiany stanowiska zajmowanego przez Tertuliana, w tym miejscu jedynie na tych wnioskach poprzestaje. Dopiero rozdział dziesiaty podejmuje poniekąd tę myśl, ale także przesuwa się po jej powierzchni sygnalizując jedynie problematykę.

Jeśli zrozumiałym jest, że w końcowej części opracowania (rozdz. 10) Autor pisze, iż ,poszukiwania związane z działalnością literacką Tertuliana dotyczą w naszym wieku głównie czterech płaszczyzn" (s. 82-83). W tym miejscu jedynie dokonując słusznego podziału oraz prezentacji owych zagadnień (1. „regula fidei” 2 . „stosunek do res publika i wspólnoty pogańskiej”, a także „stosunek do filozofii antycznej” 3. „aspekt współczesnych studiów [...] lingwistycznych i literackich" s. 83-84). Nie wnika jednak w treść problematyki, ponieważ oczywistą jest rzeczą że każde z zagadnień wymaga szerokiego opracowania, a nadto mówią one jedynie o współczesnych dyskusjach wokół postaci Tertuliana. To rozwinięcie wniosków z rozdziału trzeciego byłoby wielce wskazane. Autor bowiem doprowadza czytelnika do wyraźnie istotnego punktu swoich rozważań, a następnie zadowala się tak znacznym ich uogólnieniem i pozostawia tę, skądinąd doskonałą myśl, zupełnie nie rozwiniętą. Wystarczyło podać jako przykład przynajmniej jeden najbardziej znamienny, rys spuścizny duchowej Kartagińczyka, którym jest dziedzictwo pojęć związanych z praktyką pokutną.

Tertulian był adwokatem i to bardzo dobrym, co widać doskonale w jego apologetycznych dziełach, o czym ks. Turek ciekawie i bez zarzutu pisze w dalszej części opracowania (rozdz. 6, 7, ss. 41-62). Ale właśnie jako 
adwokat nie potrafił niestety wyzwolić się ze swego prawniczego podejścia przy rozpatrywaniu zagadnień związanych $\mathrm{z}$ dyscypliną pokutną. Nie było to wielkim błędem, jednakże sprawiło, że nie zrozumiał sensu łagodzenia tejże dyscypliny, ponieważ $w$ gruncie rzeczy nie zrozumiał zastapienia prawa przez miłosierdzie. Co zresztą w jakiś sposób „pokutuje” do dnia dzisiejszego w Kościele zachodnim, który przejął ukute przez Tertuliana słownictwo łacińskie, mocno zakotwiczone w rzymskiej, prawniczej mentalności tego pisarza (Tertulian przystosował ok. 1000 nowych wyrazów, dla potrzeb Kościoła, z czego jego następcy przejęli ponad 500, które praktycznie zachowały się do dziś, niektóre najwyżej w nieco zmienionej formie. Mowa tylko o słowach, a przecież za nimi idzie cały sposób rozumienia pewnych zagadnień, w tym i zagadnień pokutnych. (Por. np.: M. Cytowska, Literatura rzymska okresu cesarstwa. Autorzy chrześcijańscy, Warszawa 1994, s. 58-62). W ten sposób Tertulian utkwił w skrajnym nurcie integryzmu, który bardziej przypominał, pod względem przywiązania do jurydycznej formy, zwalczaną przez niego Synagogę, niż Kościół chrześcijański (por. Tertulian, Przeciw Żydom, PSP XXIX, Warszawa 1983, s. 182-219). Powyższe niedopatrzenie jest właściwie jedynym punktem „zaczepnym” w całym opracowaniu, gdyż w dalszej części, na ile to jest możliwe przy tak mimo wszystko krótkim przeglądzie tematyki, Autor przeprowadza konsekwentna i systematyczną analizę życia i działalności Tertuliana.

Tertulian montanista, czyli członek ruchu, który był „istotnie różniącym się od wszystkich innych heretyckich teorii pierwszych wieków, reprezentował pewien bunt $\mathrm{w}$ łonie samego Kościoła, pogłębiając idee mesjańskie i prorockie, których Kościół wprawdzie nie wykluczał, ale interpretował w granicach wyznaczonych przez hierarchię" (s. 32) ${ }^{3}$. Ta wstępna myśl, którą ks. Turek rozpoczyna refleksję nad montanizmem Tertuliana, a w szerszym kontekście nad zachodnim obliczem tej herezji, zawiera właściwie kwintesencję sporu nabrzmiałego wokół tego trudnego zagadnienia. Ponieważ w Kościele zachodnim, dla którego świętość, tak pojedynczego człowieka, jak i całej wspólnoty, była w pierwszych wiekach jednym z podstawowych mierników przynależności do Chrystusa, istniał bardzo silny nurt przedkładający tę świętość nad wszelkie inne cechy chrześcijaństwa. Był to powód dla którego niejednokrotnie dochodziło do walki stronnictwa integrystów (dziś powiedzielibyśmy fundamentalistów) z nurtem łagodnym. Spór ten, na początku III wieku, wyraził się przychylnością z jaką spotkała się wschodnia herezja - montanizmu, u radykalniejszych rzeczników Kościoła na czele z Tertulianem. Należy jednak dodać, że afrykańscy zwolennicy tego

${ }^{3}$ Montanizm był jednym z wielu ruchów o podłożu chiliastycznym. Charakteryzował się jednak nie tylko surową praktyką ascetyczną (tak jak inne ruchy milenarystyczne), ale dodawał do tego reformę Kościoła. Szczególnie Kościoła instytucji, który miał zostać wyzwolony przez Kościół duchowy. Montaniści uważali, że w ten sposób nawiązują do pierwotnego chrześcijaństwa, w którym Duch Święty działał bezpośrednio na swych wybranych, stąd też silnie zaakcentowanie przeżyć ekstatycznych jako potwierdzenie obecności Ducha Świętego wśród członków tego ruchu. 
„buntu w łonie samego Kościoła” (s. 32), z reguły odrzucali jego doktrynalną warstwę, która zresztą na początku praktycznie nie istniała. Również ekstatyczne uniesienia i wizyjne imaginacje proroków tego ruchu traktowali $\mathrm{z}$ dużym dystansem. Doskonale natomiast przyjęła się warstwa dyscyplinarna herezji, która miała stanowić środek, prowadzący do celu jakim było zachowanie pierwotnej radykalnej gorliwości.

Kartagińczyk, posiadając rzymskie wykształcenie rozumiał potrzebę wytworzenia i rozwoju struktur w Kościele, buntował się jednak przeciw spychaniu na plan dalszy, zaangażowanych w życie wspólnoty, ludzi świeckich. Dla niego było to: po pierwsze, rozbijanie wspólnotowego charakteru Kościoła; a po drugie, zatracanie pierwotnego ducha gmin chrześcijańskich. Jego radykalizm natomiast szukał zdecydowanych rozwiązań, kiedy więc do Afryki trafiają takie ze Wschodu, właśnie w postaci montanizmu, nie zastanawia się długo. Była to dla niego odpowiedź na dręczące go pytanie: dlaczego Kościół tak łagodzi wymogi dyscypliny moralnej względem chrześcijan? Odpowiedź: ponieważ pierwotny Ecclesia Spiritus (Kościół ducha) został zastapiony przez struktury, zaś homines spirituales (ludzie duchowi - do których przemawia Duch święty) zostali niemal całkowicie odsunięci, od działania, a ich miejsce zajmował Kościół strukturalny. W związku z tym Duch Święty nie wypowiada się już tak jasno w Kościele, jak to było wcześniej, gdyż nadal mówi do ludzi duchowych, którzy nie mają już jednak wpływu na zasadnicze decyzje o kształtowaniu się oblicza Kościoła. Wniosek: aby utrzymać pierwotną gorliwość należało - według niego, przywrócić właściwy porządek rzeczy. Do głosu mieli dojść ludzie duchowi, którzy powinni przywrócić duchowe oblicze Kościoła, a wtedy nadal prowadzony przez Parakleta będzie zmierzał do świętości. „Pisarz jest bowiem znakiem i wyrażeniem obecnej we wszystkich czasach Kościoła tendencji w kierunku aktualizacji ideału świętości i doskonałości eschatologicznej” (s. 21).

W powyższym świetle nieco jaśniejszym staje się Tertulianowy ostry atak na: „Ecclesia numerus episcoporum” - Kościół liczby biskupów - Kościół hierarchiczny (Tertulian, De Pudicitia, PL. 2, 1080). Była to bowiem w rzeczywistości próba ponownego rozciagnięcia poczucia odpowiedzialności za kształtowanie się oblicza Kościoła na wszystkich jego członków. Ponieważ odpowiedzialność ta, z chwilą wykształcenia się silniejszych struktur w Kościele przesuwała się właśnie na nie, zwalniając niejako od tego zadania laicką część chrześcijan. Pierwotny prezbiterialny ustrój Kościoła odchodził w zapomnienie, a jego miejsce, jak już zostało powiedziane, zajmował Kościół hierarchiczny, z czym Kartagińczyk w żadnej mierze nie potrafił sie pogodzić. Dla Tertuliana - radykała, było to działaniem niezrozumiałym, należało zareagować, co teź czyni z typowym dla siebie zapałem połączonym niestety $\mathrm{z}$ brakiem umiaru i popadaniem w skrajności (por. Tertulian, De Pudicitia, PL. 2, 1030-1083). Tertulian, czego nie kryje, wyraźnie przedstawia stanowisko montanistyczne, ale dziś patrząc z perspektywy czasu, czyż nie nasuwa się myśl o bliskości prawdy wokół, której krążył Kartagińczyk. Prawdy o tym, że cały Kościół, tak w osobach pojedynczych chrześci- 
jan (min. poprzez sakramenty), jak i w hierarchii (min. poprzez Nauczycielski Urząd Kościoła), rzeczywiście prowadzony jest przez Ducha Świętego (por. KKK, 688, s. 173). Były to jednak dopiero pierwsze lata III wieku (pierwszy Sobór Powszechny - Nicea 325), a początek wypracowywania podstaw pod ekleziologię zacznie czynić dopiero św. Cyprian (†258), a i ten nie ustrzegł się przecież $\mathrm{w}$ tym względzie potknięć. Gdy przychodzi nam więc dziś chęć surowego oceniania, tego niespokojnego ducha - jakim był Tertulian, warto sobie przypomnieć kiedy, dla kogo i w jakich warunkach tworzył on swoje dzieła.

W drugiej części opracowania (rozdz. 6-9) przeprowadzona została celna charakterystyka twórczości Tertuliana. Autor dokonuje ciekawych konfrontacji traktatów z rzeczywistościa, w która miały one trafić, a także, co ciekawe uwzględnia wzajemne relacje jakie między tymi traktatami występowały. Dla czytelnika ważnym jest fakt, że zanim przejdzie do lektury tekstów źródłowych zaopatrzony zostanie w niezbędną wiedzę o sposobie, metodzie i charakterze pisania Kartagińczyka. Dodatkową zaletą tych rozdziałów jest to, że przeprowadzają one odbiorcę przez problematykę społeczna, religijną i teologiczną z jaką przyszło się borykać chrześcijanom na początku III wieku. Dzięki czemu zrozumiałe stają się poruszane w przytaczanych później traktatach zagadnienia. Wszystkie te rozważania toczą się oczywiście w oparciu o stałą podstawę, która stanowią traktaty Tertuliana. Ks. Turek, trzeba to przyznać, czuje się w tym fragmencie opracowania najswobodniej, łatwość z jaką przechodzi przez skomplikowane zagadnienia teologiczne, czy filologiczne (s. $51 \mathrm{nn}$.) upewnia czytelnika, że ma do czynienia z pracą wartościową pod względem naukowym. Ale, co również należy podkreślić, ta swoboda przyczynia się również do ułatwienia odbioru. Tematyka choć nie należy do łatwych (m.in. zagadnienia dogmatyczne: Trinitas, monarchia, oeconomia), to przejrzystość stylu, z jednej strony i pewność z jaką Autor prezentuje ową problematykę, $\mathrm{z}$ drugiej; czynią ją rzeczywiście przystępną i zrozumiałą. Ten fragment opracowania stanowi nienaganne przejście od części pierwszej - opracowania, do części drugiej - wybór tekstów.

Wybór tekstów źródłowych jest dość bogaty. Z grona 31 traktatów Tertuliana w większym bądź mniejszym stopniu przytoczono 19, koncentrując się na kluczowych w jakiejś konkretnej dziedzinie. O czym łatwo się samemu przekonać po konfrontacji tych dzieł $\mathrm{z}$ rozdziałem piąym pierwszej części (a pośrednio z rozdz. 6-9), w którym dokonano krótkiego, ale rzeczowego podziału pism ze względu na: czas ich powstania, stosunek do Kościoła katolickiego i rolę jaką miały do spełnienia. Teksty źródłowe zaprezentowane zostały w trzech częściach: obrona chrześcijan, doktryna chrześcijańska i życie chrześcijan, których zastosowanie po przeczytaniu opracowania wydaje się jak najbardziej słuszne i uzasadnione. W każdej części zaprezentowane zostały fragmenty $\mathrm{z}$ adekwatnych $\mathrm{w}$ danym zagadnieniu traktatów, które w naturalny sposób dzielą ten fragment pracy na rozdziały. Zestawienie tekstów, jak każdy wybór, z samej zasady jest rzeczą subiektywną. Tak więc zadawanie sobie pytania, czy taki wybór jest trafny lub czy jest uzasadniony, 
byłoby niewłaściwe. Należy raczej zadać pytania: po pierwsze, co taki układ tekstów źródłowych za sobą niesie? Po drugie, do czego zmierza? A przede wszystkim, jaki wizerunek Tertuliana kreśli? No bo przecież tego należy oczekiwać, mając na uwadze główny temat XV tomu serii Ojcowie Żywi.

Na pochwałę zasługuje jeszcze zaprezentowana bibliografia przedmiotu i podmiotu. Jeśli bowiem przy okazji prezentowanego przez ATK wyboru traktatów Tertuliana (Tertulian, Wybór pism II, PSP XXIX, Warszawa, 1983), pan Czesław Mazur dokonał prezentacji bibliografii. Była to jednak tylko bibliografia tekstów źródłowych tłumaczonych na j. polski oraz wszystkich opracowań, także jednak tylko w j. polskim. Ks. Turek aktualizuje obie powyższe bibliografie, a co ważniejsze dodaje podstawową bibliografię w języku obcym oraz wydania krytyczne dzieł Tertuliana. Rzetelnie przygotowane Indeksy świadczą o chęci uczynienia przejrzystym całego opracowania. W tym miejscu jedynym niedociągnięciem może być brak indeksu dzieł Tertuliana zawartych w pracy. Bowiem przy zastosowaniu cytatów jako tytułów rozdziałów, co uczynił Autor w drugiej części pracy (nie zamieścił on jednak w spisie treści obok cytatu odniesienia do traktatu, z którego dany cytat pochodził), indeks taki stałby się wielce pomocny.

Po przeczytaniu tekstów źródłowych wraz z opracowaniem, rodzi się jedna zasadnicza refleksja, że skrajny rygoryzm Tertuliana, który wypływał w dużej mierze $\mathrm{z}$ tendencji chiliastycznych (milenarystycznych), modnych w ówczesnym kościele, powiedzmy tak jak dzisiaj pluralizm chrześcijański. Zjawisko akceptowane dopóty, dopóki nie przekracza granic doktrynalnych. Ten właśnie rygoryzm byłby do przyjęcia, gdyby Tertulian zachował go do własnego wyłącznie użytku, a nie próbował narzucić całemu otaczającemu go środowisku chrześcijańskiemu. Prawda była jednak taka, że od niego jako od prezbitera (?), albo od katechisty (?), ale na pewno od osoby, z którą środowisko chrześcijańskie bardzo się liczyło, oczekiwano pomocnych odpowiedzi, na zasadnicze pytania dotyczące życia Kościoła. Jak więc w takiej sytuacji miał się wypowiadać tym bardziej, że po okresie pierwotnej gorliwości wierni zaczęli ulegać tendencji łagodzenia wymagan moralnych. Tertulian był świadkiem tego, że życie codzienne zaczyna z wolna „wciagać" chrześcijan, a oni mu się powoli poddają, idąc $w$ wielu sprawach na kompromis, co wcześniej byłoby nie do pomyślenia. Kartagińczyk, widział to i walczył o utrzymanie za wszelką cenę choć grupki „godnych" chrześcijan - był zdesperowany i daleki od łagodności Mistrza, któremu służył. Jednak uważny czytelnik jego dzieł, zawartych w drugiej części tomu, dostrzeże w nich poza strona merytoryczna (dajaca odpowiedź na kolejny problem z jakim spotykała się gmina chrześcijańska), również głęboką warstwę osobistą. Ten ciaggły rozwój, ciagłe dorastanie do ewangelicznego wzorca, do którego Tertulian przez całe swe życie zmierzał. Jeśli bowiem coraz wyżej podnosił poprzeczkę wymagań moralnych, to osobiście stawał przed nimi w pierwszym rzędzie. Dramat polega na tym, że nie znajduje ludzi, mogących mu pomóc zrozumieć to, co wokół niego się dzieje. Innymi słowy: Tertulian - montanista, nie miał tyle szczęścia, co Augustyn - manichejczyk, który słuchał kazań Ambrożego, 
a porad udzielał mu doświadczony kapłan Symplicjan. Był on sam, „skazany” niejako na swą moralną nieustępliwość, która nieuchronnie prowadziła go na rubieże chrześcijaństwa.

Do tej pory ukuty został powszechny niestety pogląd, który stawia Tertuliana w zdecydowanie nieprzyjaznym świetle: jako heretyka, ewentualnie schizmatyka, a w najlepszym wypadku skrajnego rygorystę. Ks. Turek z dużym obiektywizmem, nie siląc się na wymuszoną polemikę po prostu poddaje analizie człowieka, który znalazł się w określonych warunkach religijno-społecznych, a do tego sam był postacią wielce skomplikowaną. Bodaj najciekawszą analizę Tertuliana napisał, w j. polskim, bp Tomczak: „Wielce zlożona umysłowość Tertuliana tkwi korzeniami w kulturze grecko-rzymskiej, której wszystkie soki $w$ siebie wchtonal, rozgatęzia sie jednak konarami juz w przestworzach idei chrześcijańskich, zaszczepionych na pniu natury bujnej goracej, wybuchowej, szorstkiej, śmiatej i samodzielnej. Stad jej oryginalność $i$ indywidualizm, stąd też jednak $i$ niełatwość jej rozbioru i sprawiedliwej oceny" (Tomczak K., Zagadnienia filozoficzne u Tertuliana, „Przegląd Teologiczny" 4 [1925], z. 3, s. 320). Ks. Turek nie czyni swej analizy może tak obrazową jak bp Tomczak, ale po lekturze książki czytelnik bez trudu sam dochodzi do podobnych wniosków; a mianowicie: że czerń i biel to nazbyt mało, aby uczciwie odmalować tak barwną postać jak Tertulian. Zamykając rozważania na temat XV tomu z serii Ojcowie Żywi, można powiedzieć, że jest to pozycja ze wszech miar godna polecenia. W obecnym czasie, gdy na półkach księgarskich coraz więcej zalega pseudohistorycznych sensacyjek to, tom ów stanowi godną polecenia lekturę. Łaczy on bowiem w sobie dwie ważne cechy: $z$ jednej strony, jest dobra pracą naukowa; a $\mathrm{z}$ drugiej, dzięki swej przystępnej formie, może być popularyzatorem wiedzy na temat antyku chrześcijańskiego. 